\title{
2018 Yılı Liseye Geçiş Sınavı (LGS) Matematik Sorularının Öğrenme Alanları ve Yenilenmiş Bloom Taksonomisi Bağlamında Değerlendirilmesi*
}

\section{Evaluation Of High School Entrance Exam (LGS) 2018 in Terms of Mathematics Learning Field and Revised Bloom Taxonomy}

Onur Ekinci, ${ }^{a}$ Ayten Pinar Bal ${ }^{* *}$

${ }^{a}$ Uzman Öğretmen, Milli Eğitim Bakanlığı, Adana/Türkiye. ORCID: 0000-0003-2694-9655

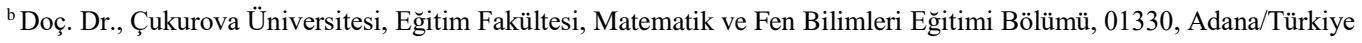
ORCID: 0000-0003-1695-9876

\section{MAKALE BİLGISI}

Makale Geçmişi:

Başvuru tarihi: 21 Eylül 2018

Düzeltme tarihi: 20 Ekim 2018

Kabul tarihi: 01 Kasım 2018

Anahtar Kelimeler:

Liseye Geçiș Sınavı

Matematik dersi

Yenilenmiş Bloom Taksonomisi

Öğrenme alanı

\section{ARTICLE INFO}

\section{Article history:}

Received 21 September 2018

Received in revised form 20 October 2018

Accepted 01 November 2018

\section{Keywords:}

LGS

Mathematics lesson

Revised Bloom taxonomy

Learning area
ÖZ

$\mathrm{Bu}$ araştırma, İlköğretim Matematik Dersi 5., 6., 7. ve 8. Sinıflar öğretim programında yer alan öğrenme alanlarıyla, 2018 yılı Liseye Geçiș Sınavı'nda sorulan Matematik dersi soru alanları arasındaki ilişkinin belirlenmesi ve bu sorular ile Yenilenmiş Bloom Taksonomisine göre hangi düzeyde bilişsel süreçlerin ölçüldügüunün ortaya çıkarılması amaçlanmıştır. Araştırma verileri nitel araştırma yöntemi çerçevesinde doküman incelenmesi ile elde edilmiştir. Sınav toplam 20 matematik sorusu içermektedir. Verilerin analizinde betimsel istatistikten yararlanılmıştır. $\mathrm{Bu}$ bağlamda öncelikle soru tipleri Yenilenmiş Bloom taksonomisi kapsamında incelenerek, sorular çeşitli alt başlıklar altında toplanmıştır. Ayrıca, uzman görüşlerinden de yararlanılarak, yapılan analizin güvenirliği kontrol edilmiştir. Araştırmanın sonucunda ise LGS soru tiplerinin, Yenilenmiş Bloom Taksonomisinin sadece uygulama ve analiz etme basamaklarındaki bilişsel süreçleri ölçtügü sonucuna ulaşılmıştır.

\section{A B S T R A C T}

The aim of this research is to determine the level of cognitive skills by comparing the Mathematics course questions asked in 2018 with the learning areas of 5th, 6th, 7th and 8th grade curriculum of Elementary Mathematics Teaching Program. The research data was obtained through a document review in the context of the qualitative research method. The exam consisted of 20 Mathematics questions. Descriptive statistics was used during the analysis of the data. The reliability of the analysis was re-examined according to expert opinions. As a result of this research analysis, it is seen that the LGS questions measure the cognitive skills only at the stages of application and analysis.

\section{Giriș}

Bütün öğretim kurumlarının genel amacı öğrencileri ilgi alanları ve yetenekleri doğrultusunda mesleğe, iş hayatına veya bir sonraki öğretim seviyesine hazırlamaktır (Gedikoğlu, 2005). Bu bağlamda, özellikle öğrencilerin lise ve üniversite tercihlerinde bu kurumlara olan yoğun taleplerini karşılayabilmek için; onların bilgi düzeyleri ve alana yatkınlıklarını doğru bir şekilde ölçen objektif bir ölçme ve değerlendirme sistemine ihtiyaç vardır (Şad ve Şahiner, 2016). Bu kapsamda ülkemizde de 8 yıllık kesintisiz eğitim sonrasında derslerin kazanımlarını ve öğrencilerin başarılarını ölçen Ortaöğretim Kurumları Seçme ve Yerleştirme Sınavı (OKS), Seviye Belirleme

\footnotetext{
*Bu çalışma, 3-6 Temmuz 2018 tarihlerinde İstanbul'da düzenlenen “International Conference on Mathematics: An Istanbul Meeting for World Mathematicians" kongresinde sözlü bildiri olarak sunulmuştur.

** Sorumlu yazar/Corresponding author

e-posta: onurekinci12@gmail.com
} 
Sınavları (SBS) ve Temel Eğitimden Ortaöğretime Geçiş (TEOG) ve en son Liseye Geçiş Sınavı (LGS) gibi merkezi ölçme ve yerleştirmeye dayanan sınavlar uygulanmıştır.

Matematik programları açısından bakıldığında ise, bu sinavlarda sorulan soruların tüm öğrenme alanları göz önünde bulundurularak hazırlandığı görülmektedir (MEB, 2018). Bu kapsamda öğrenciler sırası ile sayılar ve işlemler, cebir, geometri ve ölçme, veri işleme ve olasılık öğrenme alanları açısından sınanmıştır (MEB, 2018). Sayılar ve İşlemler öğrenme alanında sorulan sorularda, öğrencilerden doğal sayılar, tam sayılar ve rasyonel sayılarla ilgili işlem yapabilme ve bunlarla ilgili problemleri çözmeleri beklenmektedir. Cebir öğrenme alanına ilişkin olarak cebirsel ifadeleri, özdeşlikleri, çarpanlara ayırmayı, birinci ve ikinci dereceden denklemleri ve eşitsizlikleri ve ilgili problemleri çözmeleri beklenmektedir. Geometri ve ölçme öğrenme alanına ilişkin temel geometrik kavramları, iki ve üç boyutlu şekillerin özelliklerini bilmeleri ve bunlarla ilgili problemleri çözmeleri beklenmektedir. Veri İşleme konusuna ise uygun veri ile tablo ve grafikler hazırlaması ve bunları yorumlaması beklenmektedir. Olasılık öğrenme alanında ise öğrencilerden, bir olaya ait olası durumları ve farklı olasılıklara sahip olayların olma olasılıklarını hesaplamaları beklenmektedir. Bu kapsamda, Milli Eğitim Bakanlığı (2017) tarafından yayınlanan örnek sorularda da bu öğrenme alanlarına yönelik sorular olduğu ve bu soruların Yenilenmiş Bloom Taksonomisi bağlamında uygulama düzeyinde yer aldığı görülmektedir (MEB, 2017).

Öte yandan, bu tür sınavlarda sorulan soruların daha çok Bloom Taksonomisinin bilişsel öğrenme seviyeleri göz önünde bulundurularak hazırlandığı görülmektedir (Ralph, 1999; Thompson, 2008). Bloom'un orijinal Taksonomisi bilgi, kavrama, uygulama, analiz, sentez ve değerlendirme olmak üzere altı basamaklardan oluşmaktadır. $\mathrm{Bu}$ basamaklar hiyerarşik olarak basitten karmaşı̆̆a ve somuttan soyuta göre siralanmıştır (Bümen, 2006; Krathwohl, 2002). Ancak zaman içerisinde yapilan eleştiriler doğrultusunda bilgi basamağının hem eylem hem de isim özelliği taşımasından dolayı Anderson ve Krathwohl (2001) öncülüğünde Bloom Taksonomisi geliştirilerek iki boyuttan oluşan Yenilenmiş (Revize edilmiş) Bloom Taksonomisi olarak karşımıza çıkmıştır (Anderson ve Krathwohl, 2014, Krathwohl, 2002). Buna göre Yenilenmiş Bloom taksonomisinde isim öğesi Bilgi Boyutu, eylem öğesi de Bilişsel Süreç Boyutu olarak tanımlamıştır. Bilgi boyutu; "olgulara dayanan bilgi", "kavramsal bilgi”, "işlemsel bilgi" ve "biliş ötesi bilgi”den oluşurken bilişsel süreç boyutu ise "hatırlamak", "anlamak", "uygulamak", "analiz etmek", "değerlendirmek" ve "sentez yapmak" basamaklarından oluşmaktadır.

Literatürde merkezi yerleştirme sınavlarında yer alan soru tiplerini inceleyen araştırmaların genelde Bloom Taksonomisi üzerine yoğunlaştığı görülmektedir (Arı ve Gökler 2012; Özmen, 2005; Köğce ve Baki, 2009; Özer Keskin ve Aydın, 2011; Sönmez, Koç ve Çiftçi, 2013;
Dursun \& Aydin-Parim, 2014; Dalak, 2015; Kala, 2015 ve Bindak, 2017; Keleş ve Hacısalihoğlu Karadeniz, 2015; Topçu, 2017). Ancak bu çalışmalar kapsamında, liseye geçiş sınavında yer alan matematik sorularını irdeleyen sınırlı sayıda çalışma göze çarpmaktadır (Dalak, 2015; Karaman ve Bindak, 2017). Bu bağlamda, örneğin Dalak (2015) çalışmasında temel öğretimden orta öğretime geçiş sınavlarında yer alan sorular ile sekizinci sınıf öğretim programında yer alan kazanımların Yenilenmiş Bloom Taksonomisine göre ilişkisini incelemiştir. Araştırma sonucunda Dalak (2015), matematik soruları ile kazanımların yenilenmiş Bloom taksonomisine göre en az \%50 düzeyinde uyumlu olduğu sonucuna ulaşmıştır. Yine, Karaman ve Bindak (2017) ise çalışmalarında ilköğretim matematik öğretmenlerinin sınav soruları ile temel eğitimden ortaöğretime geçiş sınavındaki matematik sorularının Yenilenmiş Bloom Taksonomisi'ne göre dağılımını incelemişlerdir. Araştırma sonucunda, temel eğitimden merkezi orta öğretime geçiş sınavındaki matematik sorularının daha çok kavramsal ve bilgi türünde olduğu ve bilişsel süreç boyutunda da kavrama ve uygulama düzeyindeki sorulardan oluştuğu bulgusuna ulaşılmıştır. Benzer şekilde, Dursun ve Aydın-Parım, (2014) da çalışmalarında üniversiteye giriş sınavında sorulan matematik sorularını Bloom'un sınıflandırması çerçevesinde karşılaştırmışlardır. Araştırmanın sonucunda üniversite giriş sınavındaki matematik sorularının Bloom'un bilişsel basamaklarından uygulama basamağı göz önünde bulundurularak hazırlandığı bulgusuna ulaşmışlardır. Yukarıda değinilen sınırlı çalışmalara katkı sağlaması amacı ile yürütülen bu çalışmanın temel amacı da 2018 yılında uygulanmaya başlanan Liseye Geçiş Sınavı (LGS) matematik sorularının bilişsel düzeyler ve öğrenme alanları bağlamında irdelemek ve bu soruların Yenilenmiş Bloom Taksonomisi kapsamında hangi bilgi düzeyini ve hangi bilişsel süreçleri ölçtüğünü ortaya çıkarmaktır.

$\mathrm{Bu}$ genel amaç doğrultusunda aşağıda değinilen araştırma sorularına da yanıt aranacaktır:

1) 2018 Liseye Geçiş Sınavı (LGS) matematik sorularının öğrenme alanlarına göre dağılımı nasıldır?

2) 2018 Liseye Geçiş Sınavı (LGS) matematik sorularının alt öğrenme alanlarına göre dağılımı nasıldır?

3) Matematik dersi öğretim programının öğrenme ve alt öğrenme alanlarındaki örnek soruların Yenilenmiş Bloom Taksonomisindeki bilişsel süreç boyutuna göre dağılımı nasıldir?

4) 2018 Liseye Geçiş Sınavı (LGS) matematik sorularının Yenilenmiş Bloom Taksonomisindeki bilişsel süreç boyutuna göre dağılımı nasıldır?

\section{Yöntem}

$\mathrm{Bu}$ araştırma, 2018 yılında uygulanmaya başlanan Liseye Geçiş Sınavı (LGS) matematik sorularını bilişsel süreçler ve öğrenme alanları bağlamında belirlenmesi amacıyla yapılan nitel bir çalışmadır. Araştırmanın verileri; nitel 
araştırma yöntemi çerçevesinde doküman analizi ile elde edilmiştir. Doküman, toplumsal yaşamla ilgili olguların yazılı metinler şeklinde kayıt edilmesi olarak ifade edilebilir. $\mathrm{Bu}$ yazılı metinler ya da dokümanlar; günlük, mektup, anılar, fotoğraflar gibi kişisel kayıtlar veya resmi evraklardan oluşmaktadır. (Hitchcock ve Hughes, 1995). $\mathrm{Bu}$ araştırmada da doküman incelemesi olarak matematik dersi öğretim programı ve 2018 yılı Liseye Geçiş Sınavında (LGS) yer alan 20 adet matematik sorusu irdelenmiştir (EK-1).

\section{Veri Analizi}

Araştırmada, LGS'de yer alan matematik sorularının, öğrenme ve alt öğrenme alanları ile yenilenmiş Bloom taksonomisine göre dağılımı betimsel istatistik yöntemi ile analiz edilmiştir. Bu kapsamda, öncelikle, iki araştırmacı her bir sorunun hangi kategoride yer aldığını belirlemiştir. Daha sonraki aşamada ise, iki araştırmacının yaptıkları çözüm kontrol edilerek ortak bir uyuma ulaşılmıştır (Yıldırım ve Şimşek, 2005). Yapılan analiz sürecinin güvenirliğini test etmek amacıyla sorular, konu alanında uzman altı kişinin görüşüne sunulmuştur. Son olarak, birbirine en uyumlu iki uzman arasındaki uyuşmaya bakılarak kodlayıcılar arası güvenirlik hesaplanmıştır. Bunun için Miles ve Huberman (1994) tarafından önerilen şu formül kullanılmıştır:

\section{Güvenirlik=(Görüş Birliği)/(Görüş Birliği+Görüş Ayrılığı)}

$\mathrm{Bu}$ formüle göre iki araştırmacının da aynı kodladıkları konu sayısı (32), toplam konu sayısına (40) bölünerek kodlayıcılar arası güvenirlik 0,80 olarak hesaplanmış ve analizle ilgili genel bir ortak anlayışa varılmıştır (Miles \& Hubermann, 1994). Bir sonraki aşamada ise bireysel kodlamadan sonra, araştırmacılar bir araya gelerek oluşturdukları tabloları karşılaştırmışlardır.

\section{Bulgular ve Tartışmalar}

$\mathrm{Bu}$ bölümde, araştırma soruları bağlamında elde edilen bulgular tablolar halinde sergilenmiş ve yorumlanmıştır. Araştırmanın ilk alt amacı olarak LGS 2018'deki matematik sorularının öğrenme alanlarına ilişkin dağılımı Tablo 1'de verilmiştir.

Tablo 1 incelendiğinde LGS sınavında en çok "Geometri ve Ölçme" öğrenme alanında sorulara (\%55) yer verilmiştir. Ayrıca, "Sayılar ve İşlemler", öğrenme alanı soruların \%35'ini, "Cebir" öğrenme alanı soruların \%25'ini, "Olasılık" öğrenme alanı ise soruların \%5'ni oluşturmaktadır. "Veri İşleme" öğrenme alanında ise herhangi bir soru yer almamaktadır. Öte yandan, bazı soruların (S3, S4, S5, S11, S17) ise birden fazla öğrenme alanında yer aldığı da Tablo 1'den açıkça görülmektedir. Buna sebep olarak, birçok soruda öğrenme alanlarının iç içe geçtiği gösterilebilir. Bu kapsamda sorulan sorulardan biri Şekil 1'de yer almaktadır.
Tablo 1. LGS 2018'deki Matematik Sorularının Öğrenme Alanlarına Göre Dağılımı

\begin{tabular}{cccc}
\hline $\begin{array}{c}\text { Öğrenme } \\
\text { Alan1 }\end{array}$ & Soru Kodlar1 & Yüzde \% & $\begin{array}{c}\text { Frekans } \\
\text { (f) }\end{array}$ \\
\hline $\begin{array}{c}\text { Sayılar ve } \\
\text { İşlemler }\end{array}$ & S2,S3,S4,S6,S9,S17,S20 & $\% 35$ & 7 \\
\hline Cebir & $\mathrm{S} 3, \mathrm{~S} 5, \mathrm{~S} 10, \mathrm{~S} 11, \mathrm{~S} 14$ & $\% 25$ & 5 \\
\hline $\begin{array}{c}\text { Geometri ve } \\
\text { Ölçme }\end{array}$ & $\mathrm{S} 1, \mathrm{~S} 4, \mathrm{~S} 5, \mathrm{~S} 6, \mathrm{~S} 7, \mathrm{~S} 8, \mathrm{~S} 11$, & & \\
\hline Veri İşleme & $\mathrm{S} 12, \mathrm{~S} 17, \mathrm{~S} 18, \mathrm{~S} 19$ & $\% 55$ & 11 \\
\hline Olas1lik & - & - & - \\
\hline TOPLAM & $\mathrm{S} 5$ & $\% 120$ & 24 \\
\hline
\end{tabular}

Şekil 1: "Sayılar ve İşlemler" ve "Geometri ve Ölçme" ögrenme alanlarına yönelik bir soru örneği

4.

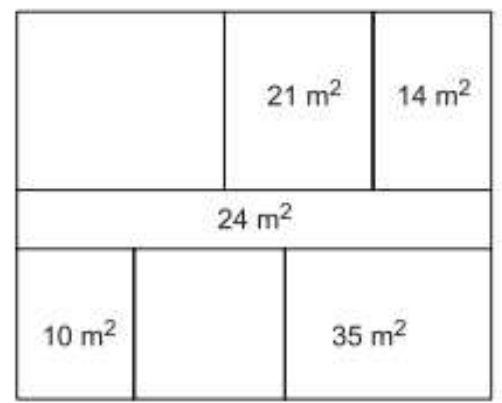

\begin{abstract}
Yukanda her bir bölümũ dikdörtgen şeklinde olan dikdörtgen biçimindeki kat planı üzerinde bazı böłümlerin alanları verilmiştir.
\end{abstract}

\section{Bu dikdörtgenlerin her birinin kenar uzun- lukları metre cinsinden birer doğal sayı olduğuna göre alanı verilmeyen bölümlerin alanları toplamı en az kaç metrekaredir?}
A) 36
B) 54
C) 64
D) 76

Şekil 1'e göre öğrencilerden sorunun çözümünde iki öğrenme alanında da yetkin olması beklenmektedir.

Araştırmanın ikinci alt amacına göre 2018 Liseye Geçiş Sınavı (LGS) matematik sorularının alt öğrenme alanlarına göre dağılımı Tablo 2'de sunulmuştur. 
Tablo 2. 2018 LGS'deki Matematik Sorularının Alt Öğrenme Alanlarına Göre Dağılımı

\begin{tabular}{|c|c|c|c|c|}
\hline $\begin{array}{l}\text { Öğrenme } \\
\text { Alanları }\end{array}$ & $\begin{array}{c}\text { Alt Öğrenme } \\
\text { Alanları }\end{array}$ & Soru Kodları & Yüzde\% & $\begin{array}{l}\text { Frekans } \\
\text { (f) }\end{array}$ \\
\hline \multirow{5}{*}{$\begin{array}{l}\text { Sayılar } \\
\text { ve } \\
\text { İşlemler }\end{array}$} & Karekök & S2,S6,S17 & $\% 15$ & 3 \\
\hline & $\begin{array}{c}\text { Çarpanlar ve } \\
\text { Katlar }\end{array}$ & S4 & $\% 5$ & 1 \\
\hline & Oran-Orant1 & S3 & $\% 5$ & 1 \\
\hline & $\begin{array}{c}\text { Rasyonel } \\
\text { Sayılarla } \\
\text { İşlemler }\end{array}$ & S9 & $\% 5$ & 1 \\
\hline & Üslü İfadeler & S20 & $\% 5$ & 1 \\
\hline \multirow{3}{*}{ Cebir } & $\begin{array}{l}\text { Cebirsel } \\
\text { İfadeler }\end{array}$ & S11 & $\% 5$ & 1 \\
\hline & $\begin{array}{c}\text { Doğrusal } \\
\text { Denklemler }\end{array}$ & S5 & $\% 5$ & 1 \\
\hline & $\begin{array}{l}\text { Denklem } \\
\text { Sistemleri }\end{array}$ & S3,S10,S14 & $\% 15$ & 1 \\
\hline \multirow{4}{*}{$\begin{array}{c}\text { Geometri } \\
\text { ve } \\
\text { Ölçme }\end{array}$} & Alan Ölçme & $\begin{array}{c}\text { S1,S4,S5,S6,S8, } \\
\text { S17 }\end{array}$ & $\% 30$ & 6 \\
\hline & $\begin{array}{l}\text { Dönüşüm } \\
\text { Geometrisi }\end{array}$ & S7 & $\% 5$ & 1 \\
\hline & $\begin{array}{l}\text { Geometrik } \\
\text { Cisimler }\end{array}$ & $\mathrm{S} 11, \mathrm{~S} 12, \mathrm{~S} 19$ & $\% 15$ & 3 \\
\hline & Üçgenler & $\begin{array}{l}\mathrm{S} 8, \mathrm{~S} 18 \\
\end{array}$ & $\% 5$ & 1 \\
\hline $\begin{array}{l}\text { Veri } \\
\text { İşleme }\end{array}$ & Veri Analizi & - & - & - \\
\hline Olasılık & $\begin{array}{c}\text { Basit } \\
\text { Olayların } \\
\text { Olma Olasılığ } 1\end{array}$ & S5 & $\% 5$ & 1 \\
\hline
\end{tabular}

Tablo 2'ye göre soruların en çok “Alan Ölçme (\%30)" alt öğrenme alanından hazırlandığı görülmektedir. Daha sonra sırası ile "Karekök" (\%15), "Denklem Sistemleri", (\%15), "Geometrik Cisimler", "Üçgenler" (\%10) alt öğrenme alanlarında sorular göze çarpmaktadır. Diğer taraftan "çarpanlar ve katlar", "oran-orantı", "rasyonel sayılarla işlemler”, üslü ifadeler”, “cebirsel ifadeler”, “doğrusal denklemler", “dönüşüm geometrisi”, "basit olayların olma olasılığı” alt öğrenme alanları ise soruların \%5'lik kısmını oluşturmaktadır. Bunların yanında "veri analizi” konusuna dair herhangi bir sorunun sorulmadığı görülmektedir. Ayrıca, bazı soruların (S3,S4,S5,S8,S11,S17) birden fazla alt öğrenme alanında yer aldığı da Tablo 2'den açıkça görülmektedir. Bu kapsamda sorulan sorulardan biri Şekil 2'de yer almaktadır:
Şekil 2: "Cebirsel ifadeler" alt öğrenme alanı ile "Geometrik cisimler" alt öğrenme alanlarına yönelik bir soru örneği

11.

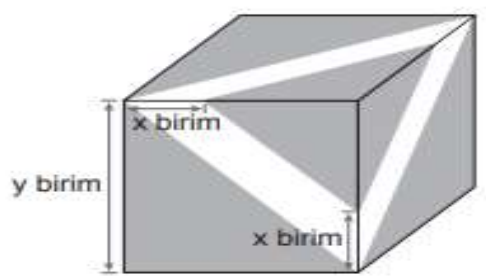

Kūp şeklindeki kutunun tüm yüzlerine şekildeki gibi eşit büyüklükte şeritler yapıştırılıyor ve şeritler dışında kalan üçgen biçimindeki bölgeler boyaniyor.

Buna göre, boyanan bölgenin alanını birimkare cinsinden gösteren cebirsel ifade aşağıdakilerden hangisidir?
A) $6 y^{2}-6 x y+3 x^{2}$
B) $3 y^{2}-6 x y+6 x^{2}$
C) $6 y^{2}-6 x y-3 x^{2}$
D) $3 y^{2}-6 x y-6 x^{2}$

Şekil 2'ye göre öğrencilerden cebirsel ifadeler alt öğrenme alanında ve geometrik cisimler alt öğrenme alanında yetkin olmaları beklenmektedir.

Araştırmanın üçüncü alt amacına göre Matematik Dersi Öğretim Programındaki öğrenme ve alt öğrenme alanlarına ait örnek soruların Yenilenmiş Bloom Taksonomisindeki bilişsel süreç boyutuna göre dağılımı Tablo 3'te yer almaktadır.

Tablo 3'e göre, yenilenmiş Bloom taksonomisindeki bilişsel süreçler boyutu kapsamında hazırlanan soruların yalnızca "Uygulama" ve "Analiz Etme" basamaklarında yer aldığı görülmektedir. Buna göre "Uygulama” basamağında sekiz soru yer alırken; "Analiz Etme" basamağında ise 12 soru bulunmaktadir.

Soruların "Uygulama”, ve “Analiz" basamaklarında yer alması, temel sebeplerinden biri: öğrenme ve alt öğrenme alanlarının iç içe, diğeri ise; çeldiricilerin sık olmasıdır. Geçmiş yıllarda yapılan TEOG sınavlarında sorular "'Bilgi', 'Kavrama"' ve "Uygulama', basamaklarında yer alırken; LGS'de en alt basamak olarak "Uygulama", basamağındadır. LGS matematik soruları kazanımlara uygun ve anlaşılır (14. soru hariç) bir dille hazırlanmıştır. 
Tablo 3. Matematik Dersi Öğretim Programındaki Öğrenme Ve Alt Öğrenme Alanlarına Ait Örnek Soruların Yenilenmiş Bloom Taksonomisindeki Bilişsel Süreç Boyutuna Göre Dağılımı

Bilişsel Süreç Boyutu

\begin{tabular}{|c|c|c|c|c|c|c|c|}
\hline 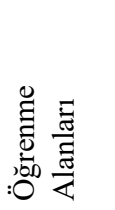 & 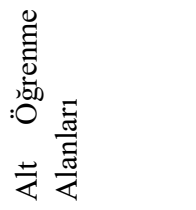 & $\underset{\stackrel{\Xi}{\Xi}}{\stackrel{\Xi}{\Xi}}$ & $\frac{\stackrel{\Xi}{\Xi}}{\frac{\Xi}{\Xi}}$ & $\begin{array}{l}\underset{\Xi}{\Xi} \\
\frac{\vec{\Xi}}{\Xi} \\
\grave{b} \\
\vec{b}\end{array}$ & 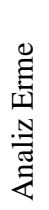 & 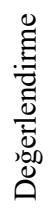 & 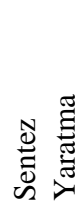 \\
\hline \multirow{4}{*}{$\begin{array}{l}\text { Sayılar } \\
\text { ve } \\
\text { İşlemler }\end{array}$} & Karekök & - & - & 1 & 2 & - & - \\
\hline & $\begin{array}{l}\text { Çarpanlar ve } \\
\text { Katlar }\end{array}$ & - & - & - & 1 & - & - \\
\hline & $\begin{array}{l}\text { Rasyonel } \\
\text { Sayilar }\end{array}$ & - & - & 1 & - & - & - \\
\hline & Üslü İfade & - & - & 1 & - & - & - \\
\hline \multirow{4}{*}{ Cebir } & $\begin{array}{l}\text { Cebirsel } \\
\text { İfadeler }\end{array}$ & - & - & 1 & - & - & - \\
\hline & $\begin{array}{l}\text { Doğrusal } \\
\text { Denklemler }\end{array}$ & - & - & - & 1 & - & - \\
\hline & $\begin{array}{l}\text { Denklem } \\
\text { Sistemleri }\end{array}$ & - & - & 1 & 2 & - & - \\
\hline & Alan Ölçme & - & - & - & 6 & - & - \\
\hline \multirow{3}{*}{$\begin{array}{c}\text { Geomet } \\
\text { ri ve } \\
\text { Ölçme }\end{array}$} & $\begin{array}{l}\text { Dönüşüm } \\
\text { Geometrisi }\end{array}$ & - & - & 1 & -- & - & - \\
\hline & $\begin{array}{l}\text { Geometrik } \\
\text { Cisimler }\end{array}$ & - & - & 1 & 2 & - & - \\
\hline & Üçgenler & - & - & 1 & 1 & - & - \\
\hline $\begin{array}{c}\text { Veri } \\
\text { İşleme }\end{array}$ & Veri Analizi & - & - & - & - & - & - \\
\hline Olasılık & $\begin{array}{l}\text { Basit } \\
\text { Olayların } \\
\text { Olma } \\
\text { Olasılığ1 }\end{array}$ & - & - & - & 1 & - & - \\
\hline
\end{tabular}

\begin{tabular}{lllllll}
\hline Toplam & - & - & 8 & 12 & - & -
\end{tabular}

Birden fazla kazanımın bir arada kullanılmasıyla oluşan sorular yer almaktadır. Güncel hayatla ilişkilendirilmiş, yoruma dayalı, çeldiricilerin yer aldığı ve öğrenci tarafindan fazla işlem gerektiren sorulardan oluştuğu görülmektedir.

$\mathrm{Bu}$ kapsamda sorulan sorulardan uygulama düzeyine ilişkin bir örnek Şekil 3'te yer almaktadır:
Şekil 3:Uygulama düzeyine ilişkin bir örnek soru

18.

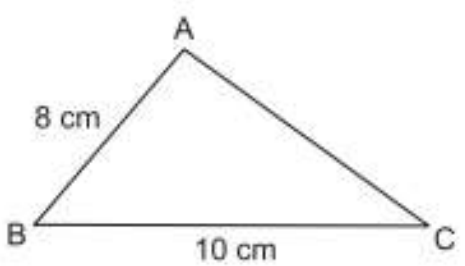

$A B C$ üçgeninde $m(\widehat{B A C})>m(\widehat{A B C})$, $|A B|=8 \mathrm{~cm}$ ve $|B C|=10 \mathrm{~cm}$ 'dir.

Buna göre $|\mathrm{AC}|$ 'nun santimetre cinsinden alabileceği kaç farklı tam sayı değeri vardır?
A) 5
B) 6
C) 7
D) 8

Şekil 3'e göre öğrencilerden üçgenlerde kenar bağıntı özelliklerini bilmeleri ve soruda bu kuralı uygulamaları beklenmektedir.

Analiz düzeyine ilişkin bir örnek ise Şekil 4'te yer almaktadır.

Şekil 4:Analiz Etme düzeyine ilişkin bir soru örneği

\section{Alanı $118 \mathrm{~m}^{2}$ olan bir evin dikdörtgen biçimin- deki odalan ve salonu dışındaki bölümlerinin toplam alanı $34 \mathrm{~m}^{2}$ dir. Salonun alanı, metre- kare cinsinden bir tamkare sayıdır ve odaların alanları toplamından küçūktür.}

Bu salonun kısa kenarının uzunluğu $\sqrt{18} \mathrm{~m}$ olduğuna göre uzun kenarının uzunluğu en fazla kaç metredir?
A) $7 \sqrt{2}$
B) $6 \sqrt{2}$
C) $4 \sqrt{2}$
D) $3 \sqrt{2}$

Şekil 4'e göre sorunun çözümü için öğrencilerden, geometrik cisimleri, alan kavramını, tam kare ifadeleri ve karekök konusunu çok iyi bilerek soruyu çözmeleri ve en fazla uzun kenarın kaç metre olacağını tahmin etmeleri beklenmektedir.

Araştırmanın son amacında ise 2018 Liseye Geçiş Sınavı (LGS) matematik sorularının Yenilenmiş Bloom Taksonomisindeki bilişsel süreç boyutuna göre dağılımı Tablo 4'te yer almaktadır. 
Tablo 4. 2018 LGS Matematik Sorularının Yenilenmiş Bloom Taksonomisine Göre Dağılımı

Bilişsel Süreç Boyutu

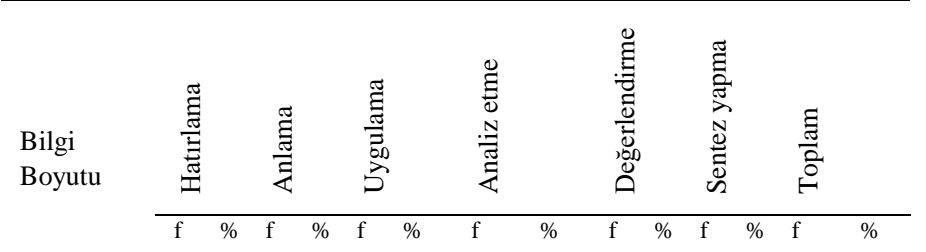

\begin{tabular}{lccccccccccccccc}
\hline Olgusal & - & - & - & - & - & - & - & - & - & - & - & - & - & - \\
\hline Kavramsal & - & - & - & - & 1 & 5 & 1 & 5 & - & - & - & - & 2 & 10 \\
& & & & & & & & & & & & & \\
\hline İslemsel & - & - & - & - & 7 & 35 & 11 & 55 & - & - & - & - & 8 & 90 \\
& & & & & & & & & & & & & & \\
\hline $\begin{array}{l}\text { Üst } \\
\text { bilişsel }\end{array}$ & - & - & - & - & - & - & - & - & - & - & - & - & - & - \\
\hline TOPLAM & 0 & 0 & 0 & 0 & 8 & 40 & 12 & 60 & 0 & 0 & 0 & 0 & 20 & 100
\end{tabular}

Tablo 4'e göre bilgi boyutunda hazırlanan soruların $\% 10$ 'u kavramsal bilgi ve \%90'ı ise işlemsel bilgi düzeyindedir. $\mathrm{Bu}$ kapsamda sorulan sorulardan biri örnek olarak Şekil 5'te verilmişsir:

Şekil 5: Kavramsal bilgi düzeyine ilişkin bir soru örneği

14.

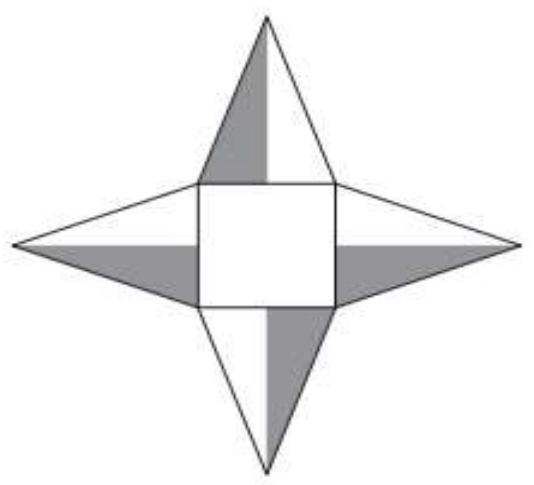

Beyaz kartondan yapılmış bir kare dik piramidin dış yüzünün bir kısmı griye boyanıyor. Bu kare dik piramidin açınımı yapıldığında dış yüzü yukarıdaki gibi görünüyor.

Buna göre aşağıdakilerden hangisi bu piramidin görünümlerinden biri olamaz?

Şekil 5'e göre sorunun çözümü için öğrencilerin kare piramidin ne olduğunu kavramaları ve buna uygun olarak çözüme ulaşmaları beklenmektedir.

Bunun yanında bu soruların hiç birinin olgusal bilgiyi ve üst bilişsel bilgiyi ölçen sorular olmadığı görülmektedir. Diğer taraftan bilişsel süreç boyutu göz önünde bulundurulduğunda ise LGS sorularının \%60'ının analiz etme ve \%40'ının da uygulama basamağında olduğu görülmektedir. Ancak bu soruların hiçbirinin hatırlama, anlama, değerlendirme ve sentez yapma basamaklarını kapsamadığı yine Tablo 4'den açıkça görülmektedir. Bu kapsamda sorulan sorulardan biri Şekil 6'da örnek olarak verilmiştir:

Şekil 6: Analiz düzeyine ilişkin bir soru örneği

\section{Bir kenarının uzunluğu $10 \mathrm{~m}$ olan kare şek- lindeki bir bahçenin sadece köşelerinde birer sulama sistemi vardır. Her bir sulama sistemi, bulunduğu köşeye uzaklığı en fazla $4 \mathrm{~m}$ olan kısma kadar sulama yapabilmektedir. Bu bah- çenin sulama yapılamayan kısmında tabanı kare şeklinde olan bir çardak bulunmaktadır. Bu çardağın tabanının köşegeni ile bahçenin köşegeni çakışıktır.}

\section{Taban köşegeninin uzunluğu metre cinsin- den bir doğal sayı olan bu çardağın taban alanı en fazla kaç metrekaredir?}
A) 18
B) 48
C) 52
D) 72

Şekil 6'ya göre sorunun çözümü için öğrencilerin geometri konusunu çok iyi bilmeleri ve çardağın taban alanının kaç metre olabileceğini hesaplamaları beklenmektedir.

\section{Sonuç ve Öneriler}

$\mathrm{Bu}$ çalışma, 2018 yılında uygulamaya başlanan Liseye Geçiş Sınavı (LGS) matematik sorularını bilişsel düzeyler ve öğrenme alanları bağlamında irdelemek ve bu soruların Yenilenmiş Bloom taksonomisi kapsamında hangi bilgi düzeyini ve hangi bilişsel süreçleri ölçtüğünü ortaya çıkarmak amacıyla yapılmıştır. Araştırmanın sonucunda Liseye Geçiş Sınavı matematik sorularının en çok "Geometri ve Ölçme" öğrenme alanı göz önünde bulundurularak hazırlandığı; ancak "Veri İşleme" öğrenme alanında ise hiçbir soruya yer verilmediği bulgusuna ulaşılmıştır. Diğer taraftan, Liseye Geçiş Sınavı matematik sorularının alt öğrenme alanlarına göre dağılımı incelendiğinde ise en çok "Alan Ölçme" alanında sorulara yer verildiği; ancak, "Veri işleme" konusunda ise hiçbir soruya yer verilmediği bulgusuna ulaşılmıştır. Buna göre soruların tüm öğrenme alanlarına yönelik olmadığ görülmektedir. Ancak matematik dersi öğretim programının 8. Sınıf öğrenme alanları ve konu dağılımları incelendiğinde tüm öğrenme alanlarına ait kazanımların olduğu ve sınav sorularının dağılımlarıyla kazanımlar arasında tam bir uyum olmadığı söylenebilir.

Yine, araştırmadan elde edilen diğer önemli bir bulgu ise matematik dersi öğretim programının öğrenme ve alt öğrenme alanlarında yer alan soruların yalnızca "Uygulama" ve "Analiz" basamaklarında olduğudur. Ancak hatırlama, anlama, değerlendirme ve sentez yapma basamaklarında ise hiçbir soruya rastlanmamıştır. Buna göre sınav sorularının öğrencilerin üst düzey düşünme becerilerini ölçme, değerlendirme yorumlama düzeylerini ölçmeye yönelik olduğu araştırmadan açıkça görülmektedir. 
Bu sonuç Ubuz ve Sarpkaya'nın (2014) çalışmasıyla da benzerlik göstermektedir. Ancak literatürde, bu çalışmayla benzerlik göstermeyen araştırmalara da rastlanmaktadır (Karaman ve Bindak, 2017; Köğçe ve Baki, 2009; Biber ve Tuna, 2017; Çintaş Yıldız, 2015). Bu durumun araştırmanın yapıldığı örneklemden kaynaklandığı söylenebilir.

Son olarak araştırmada Liseye Geçiş Sınavı matematik sorularının bilgi düzeyi açısından kavramsal ve işlemsel bilgi düzeyinde olduğu ancak olgusal bilgi ve üst bilişsel bilgi düzeyinde olmadığı bulgusuna ulaşılmıştır. Bu sonuç Karaman ve Bindak'ın (2017) çalışmasıyla benzerlik göstermektedir

$\mathrm{Bu}$ araştırma elde edilen sonuçlardan yola çıkarak, yapılacak sinavlarda soru türlerinin matematik öğretim programlarında yer alan bütün kazanım ve öğrenme alanlarına göre düzenlenmesi; ayrıca, soruların Yenilenmiş Bloom Taksonomisi bağlamında yer alan tüm düzeylere göre hazırlanması önerilebilir.

\section{Kaynakça}

Anderson, L.W. (Ed.), Krathwohl, D.R. (Ed.), Airasian, P.W., Cruikshank, K.A., Mayer, R.E., Pintrich, P.R., Raths, J., \& Wittrock, M.C. (2001). A taxonomy for learning, teaching, and assessing: A revision of Bloom's Taxonomy of Educational Objectives (Complete edition). New York: Longman.

Anderson, L.W., \& Krathwohl, D. R. (2014). Öğrenme öğretim ve değerlendirme ile ilgili bir sinıflama: Bloom'un eğitimin hedefleri ile ilgili sınıflamasının güncelleştirilmiş biçimi (Çev. D. A. Özçelik). Ankara: Pegem Akademi.

Arı, A. ve Gökler, Z. S. (2012). İlköğretim fen ve teknoloji dersi kazanımları ve SBS sorularının Yeni Bloom Taksonomisine göre değerlendirilmesi. http://kongre.nigde.edu.tr/xufbmek/dosyalar/tam_metin/ pdf/2414-30_05_2012-16_57_22.pdf adresinden 15 Ağustos 2018 tarihinde indirilmiştir.

Biber, A. Ç ve Tuna, A. (2017). Ortaokul matematik kitaplarındaki öğrenme alanları ve Bloom Taksonomisine göre karşılaştırılmalı analizi. Ondokuz Mayıs Üniversitesi Eğitim Fakültesi Dergisi 36(1): 161174.

Bümen, N. T. (2006). Program geliştirmede bir dönüm noktası: Yenilenmiş Bloom Taksonomisi. Eğitim ve Bilim, 31(142), 3-14.

Çintaş Yıldız, D. (2015). Türkçe Dersi Sınav Sorularının Yeniden Yapılandırılan Bloom Taksonomisine Göre Analizi. Gaziantep University Journal of Social Sciences, 14(2):479-497.

Dalak, O. (2015). TEOG sınav soruları ile 8. sınıf öğretim programlarındaki ilgili kazanımların Yenilenmiş Bloom Taksonomisine göre incelenmesi. Yayınlanmamış Yüksek Lisans Tezi, Gaziantep Üniversitesi Ĕ̈itim Bilimleri Enstitüsü, Gaziantep.

Dursun, A. ve Aydın Parim, (2014). YGS 2013 matematik soruları ile ortaöğretim 9. sınıf matematik sınav sorularının Bloom Taksonomisine ve öğretim programına göre karşılaștırılması. Eğitim Bilimleri Araştırmaları Dergisi, 4(1), 17-37. http://ebad-jesr.com

Gedikoğlu, T. (2005). Avrupa Birliği sürecinde Türk eğitim sistemi: sorunlar ve çözüm önerileri.Mersin Üniversitesi Eğitim Fakültesi Dergisi, 1(1), 66-80.

Hitchcock G. ve Hughes D. (1995). Research and the Teacher: A Qualitative Introduction to School Based Research (2nd Ed.), London: Routledge.

Kala, A. (2015). KPSS biyoloji alan bilgisi sorularının alan bilgisi yeterlikleri çerçevesinde Yenilenmiş Bloom Taksonomisi ile analizi: 2013 yılı örneği. Yayınlanmamıș Yüksek Lisans Tezi, Marmara Üniversitesi Eğitim Bilimleri Enstitüsü, İstanbul.

Karaman, M., Bindak, R. (2017). ilköğretim matematik öğretmenlerinin sınav soruları ile teog matematik sorularının Yenilenmiş Bloom Taksonomisi'ne göre analizi, Curr Res Educ (2017), 3(2) · 51-65.

Keleş, T. ve Hacısalihoğlu Karadeniz, M. (2015). 20062012 yılları arasında yapılan ÖSS, YGS ve LYS matematik ve geometri sorularının bloom taksonomisinin bilişsel süreç boyutuna göre incelenmesi.Turkish Journal of Computer and Mathematics Education, 6(3): 532-552

Köğce, D. ve Baki, A. (2009). Matematik öğretmenlerinin yazılı sınav soruları ile ÖSS sinavlarında sorulan matematik sorularının Bloom taksonomisine göre karşılaştırılması, Pamukkale Üniversitesi Ĕ̆gitim Fakültesi Dergisi, 26, 70-80.

Krathwohl, D. R. (2002). A revision of Bloom's taxonomy: An overview, Theory into practice, 41(4), 212-218.

MEB (2018). Matematik dersi (5-8. Sinıflar) öğretim program1,

http://mufredat.meb.gov.tr/ProgramDetay.aspx?PID=32 9 adresinden 04 Haziran 2018 tarihinde indirilmiştir.

MEB (2018). Sinavla öğrenci alacak ortaöğretim kurumlarına ilişkin merkezi sınava ait soru ve cevap anahtarlar1. [Online]: Dsgm.meb.gov.tr/www/2-haziran2018-tarihinde-yapilan-sinavla-ogrenci-alacakortaogretim-kurumlarina-iliskin-merkez-sinava-ait-soruve-cevap-anahtarlari/icerik/317 adresinden 04 Haziran 2018 tarihinde indirilmiştir.

MEB, (2017). 2017-2018 Öğretim yılı 8. sınıflar için uygulanacak sınav ait örnek sorular kitapçığı (sayısal bölüm)https://www.meb.gov.tr/sinavlar/dokumanlar/20 17/ornek_sorular_sayisal_2017.pdf adresinden 15 Ekim 2018 tarihinde indirilmiştir.

Miles, M. B., \& Huberman, A. M. (1994). Qualitative data analysis: An expanded Sourcebook.(2nded). Thousand Oaks, CA: Sage.

Özer Keskin, M. ve Aydın, S. (2011). Seviye belirleme sınavı 6. sınıf fen ve teknoloji testinde çıkan biyoloji sorularının revize edilmiş taksonomiye göre incelenmesi. Gazi Eğitim Fakültesi Dergisi, 31(3), 727742.

Özmen, H., (2005). 1990-2005 OSS Sinavlarındaki kimya sorularının konu alanlarına ve Bloom taksonomisi'ne göre incelenmesi, Eurasian Journal of Educational Research, 21, 187-199.

Ralph, E. G. (1999). Developing novice teachers' oralquestioning skills, Mcgilljournal of Education, 34(1), 29-47.

Sönmez, Ö. F., Koç, H. ve Çiftçi, T. (2013). ÖSS, YGS ve LYS sınavlarındaki coğrafya sorularının Bloom 
Taksonomisi bilișsel alan düzeyi açısından analizi. Karadeniz Araștırmaları, 36, 257-275.

Şad, S. N. ve Şahiner, Y.S. (2016). Temel eğitimden ortaöğretime geçiş (TEOG) sistemine ilişkin öğrenci, öğretmen ve veli görüşleri. Elementary Education Online, 2016; 15(1): 53-76.

Thompson, T. (2008). Mathematics teachers' interpretation of higher-order thinking in Bloom's Taxonomy. International Electronic Journal of Mathematics Education, 3(2), 96-109.

Topçu, E. (2017). TEOG tarih sorularının yenilenmiş Bloom Taksonomisine göre analizi. Uluslararası Türk Ĕ̈itim Bilimleri Dergisi, (9):321-335.

Ubuz, B., ve Sarpkaya, G. (2014). The Investigation of Algebraic Tasks in Sixth Grades in Terms of Cognitive Demands: Mathematics Texbook and Classroom Implementations. Elementary Education Online, 13(2), 594-606.

Yıldırım, A. ve Şimşek, H. (2005). Sosyal bilimlerde nitel araştırma yöntemleri. Ankara: Seçkin Yayıncılık

\section{EK-1}

1. Kenarlarının uzunlukları $6 \mathrm{~cm}$ ve $8 \mathrm{~cm}$ olan bir dikdörtgene benzer olacak şekilde, kenar uzunlukları santimetre cinsinden doğal sayı olan bir dikdörtgen çizilecektir.

Çizilecek bu dikdörtgenin alanı 48 santimetrekareden büyük olacağına göre en az kaç santimetrekaredir?
A) 96
B) 108
C) 144
D) 192

2.

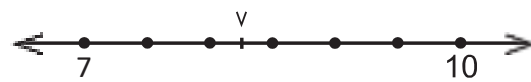

Yukarıdaki sayı doğrusunda 7 ile 10'a karşılık gelen noktaların arası 6 eş parçaya ayrılmıştır.

Buna göre A noktasına karşılık gelen sayı aşağıdakilerden hangisi olabilir?
A) $\sqrt{ } 94^{-}$
B) $\sqrt{88^{-}}$
C) $\sqrt{ } 79^{-}$
D) $\sqrt{6} 68^{-}$

3. Ahmet her gün kumbarasından aynı miktarda para alarak harcıyor. Ahmet'in kumbarasındaki para miktarı ve harcadığı toplam para miktarını gösteren doğrusal grafik aşağıda verilmiștir.

\section{Grafik: Kumbarada Bulunan ve Harcanan Toplam Para Miktarı}

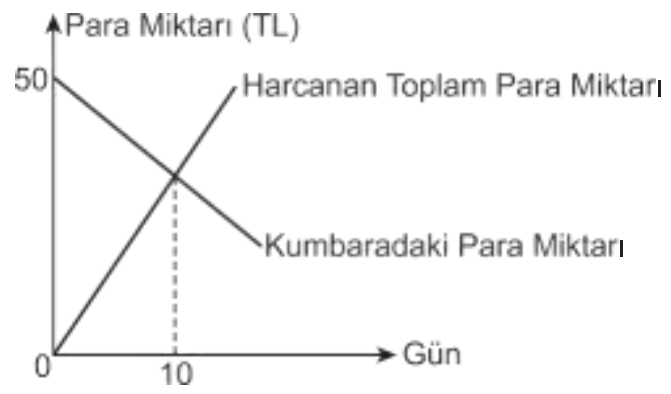

kaçıncı günde biter?
A) 20
B) 25
C) 30
D) 35

4.

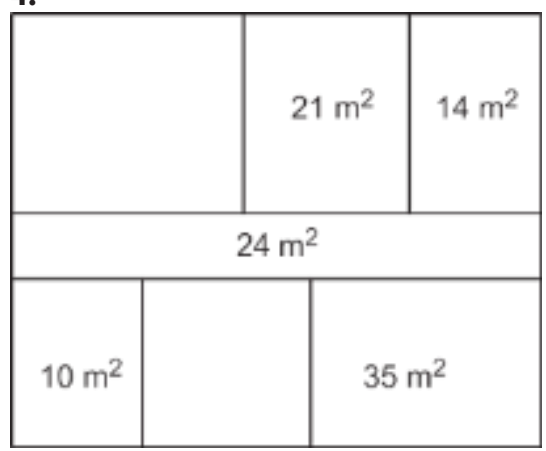

Yukarıda her bir bölümü dikdörtgen şeklinde olan dikdörtgen biçimindeki kat planı üzerinde bazı bölümlerin alanları verilmiştir.

$\mathrm{Bu}$ dikdörtgenlerin her birinin kenar uzunlukları metre cinsinden birer doğal sayı olduğuna göre alanı verilmeyen bölümlerin alanları toplamı en az kaç metrekaredir?
A) 36
B) 54
C) 64
D) 76

5. $21000 \mathrm{~m} 2$ lik bir arsa ortaklar arasında paylaştırılacaktır. Paylaşım için arsanın tamamı $250 \mathrm{~m}^{2}, 500 \mathrm{~m}^{2}$ ve $1000 \mathrm{~m}^{2}$ lik bölümlere ayrılıyor. Toplam bölüm sayısı ortakların sayısına eşittir. Her bir bölüm numaralandırılıyor ve bu numaralar özdeş kartların üzerine yazılarak boş bir torbaya atılıyor. Arsanın ortakları arasında çekilecek kura ile bu bölümlerin sahipleri belirlenecektir.

Bu kurada torbadan çekilecek ilk kartın üzerinde yazan numaranın; alanı $250 \mathrm{~m}^{2}, 500 \mathrm{~m}^{2}$ ve $1000 \mathrm{~m}^{2}$ olan bölümlerden birine ait olma olasılıkları eșit olduğuna göre bu arsanın kaç ortağı vardır?
A) 24
B) 36
C) 48
D) 60

6. Altan ve Can, defterlerine kenar uzunlukları santimetre cinsinden doğal sayı olan birer kare çiziyorlar. Altan'ın çizdiği karenin alanı kenar uzunlukları $7 \mathrm{~cm}$ ve $9 \mathrm{~cm}$ olan bir dikdörtgenin alanından büyük, Can'ın çizdiği karenin alanı ise bu dikdörtgenin alanından küçüktür.

Buna göre Altan ile Can'ın çizdiği karelerin alanları arasındaki fark en az kaç santimetrekaredir?
A) 8
B) 15
C) 32
D) 39 


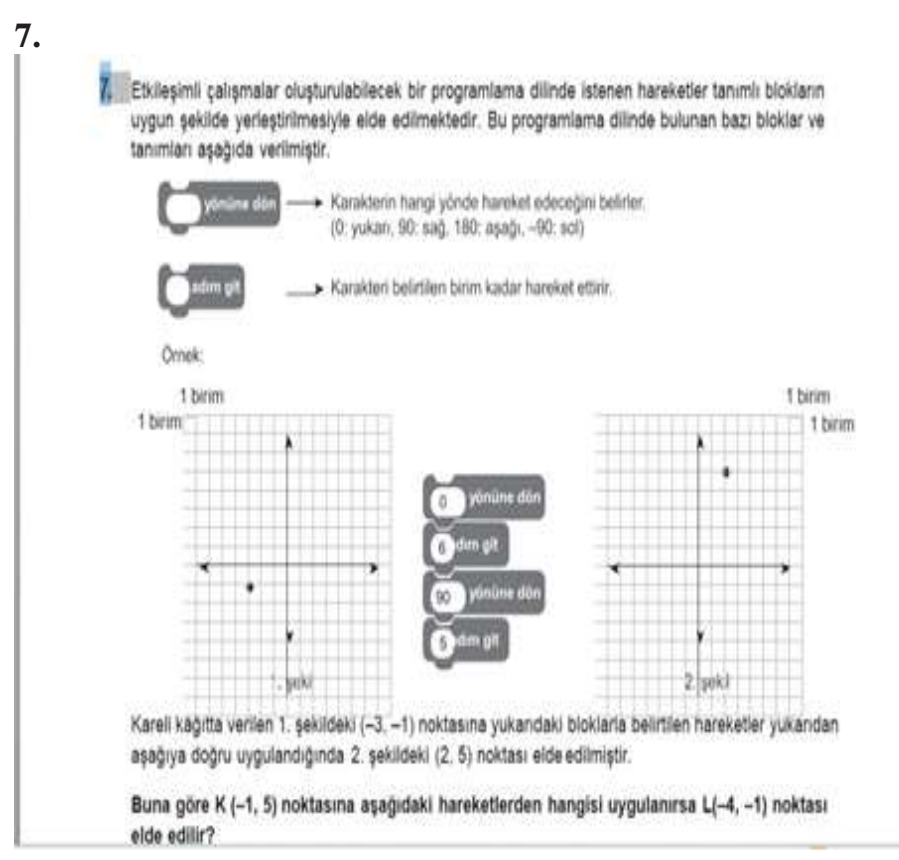

8. Bir kenarının uzunluğu $10 \mathrm{~m}$ olan kare şeklindeki bir bahçenin sadece köşelerinde birer sulama sistemi vardır. Her bir sulama sistemi, bulunduğu köșeye uzaklığı en fazla 4 m olan kısma kadar sulama yapabilmektedir. Bu bahçenin sulama yapılamayan kısmında tabanı kare şeklinde olan bir çardak bulunmaktadır. Bu çardağın tabanının köşegeni ile bahçenin köşegeni çakışıktır.

Taban köşegeninin uzunluğu metre cinsinden bir doğal sayı olan bu çardağın taban alanı en fazla kaç metrekaredir?
A) 18
B) 48
C) 52
D) 72

9. $0,00013 * 10^{\mathrm{a}}$ ifadesinin değeri 1000 'den büyüktür.

Buna göre a'nın alabileceği en küçük tam sayı değeri kaçtır?
A) 8
B) 7
C) 6
D) 5

10. Aşağıdaki tabloda bir lokantada satılan ve her gramında eşit kalori bulunan yemeklerin kütle ve kalorileri verilmiştir.

Tablo: Yemeklerin 100 Gramındaki Kalori Miktarları

\begin{tabular}{|l|l|}
\hline Yemek & Kalori \\
\hline Çorba & 45 \\
\hline Pilav & 72 \\
\hline Nohut & 40 \\
\hline
\end{tabular}

Lokantadaki yemekler her bir tabakta 100 gram yemek olacak şekilde satılmaktadır.

$\mathrm{Bu}$ lokantadan toplam 538 kalori değerinde 10 tabak yemek sipariş verildiğinde kaç tabak nohut sipariş verilmiş olunur?
A) 2
B) 3
C) 4
D) 5

11.

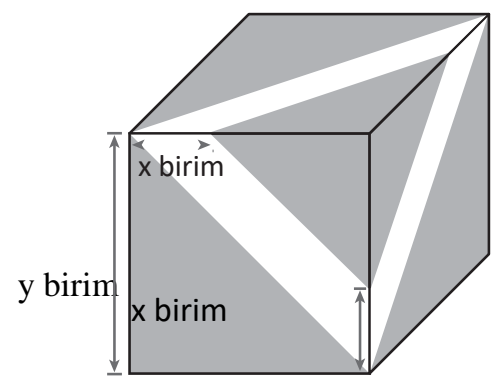

Küp şeklindeki kutunun tüm yüzlerine şekildeki gibi eşit büyüklükte şeritler yapıştırılıyor ve şeritler dışında kalan üçgen biçimindeki bölgeler boyanıyor.

Buna göre, boyanan bölgenin alanını birimkare cinsinden gösteren cebirsel ifade aşağıdakilerden hangisidir?
A) $6 y 2-6 x y+3 x 2$
B) $3 y 2-6 x y+6 x 2$
C) $6 y^{2}-6 x y-3 x 2$
D) $3 y^{2}-6 x y-6 x 2$

12. Kareli kâğıtta verilen aşağıdaki dikdörtgenler- den üçü aynı üçgen dik prizmaya ait yüzlerdir.

Buna göre hangisi bu üçgen prizmanın bir yüzü olamaz?

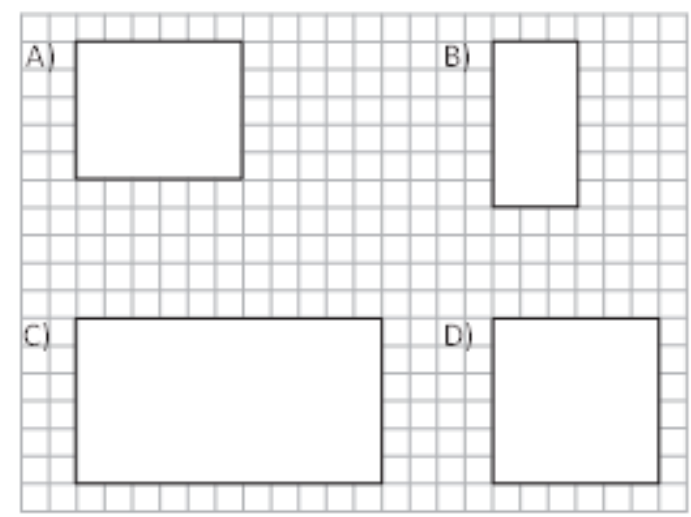

13. Aşağıdakilerden hangisi $3 x^{2}-6 x y+3 y^{2}$ cebirsel ifadesinin çarpanlarından biridir?
A) $3 x$
B ) $y-x$
C) $x+y$
D) $3 y^{2}$

14. 


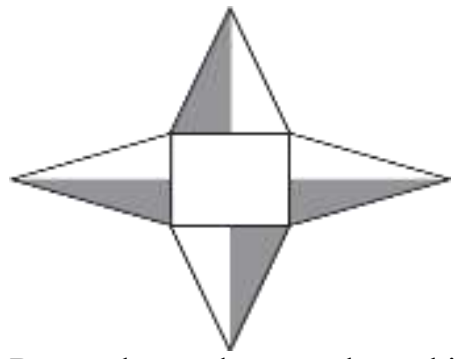

Beyaz kartondan yapılmış bir kare dik piramidin dış yüzünün bir kısmı griye boyanıyor. Bu kare dik piramidin açınımı yapıldığında dış yüzü yukarıdaki gibi görünüyor.

Buna göre aşağıdakilerden hangisi bu piramidin görünümlerinden biri olamaz?
A)

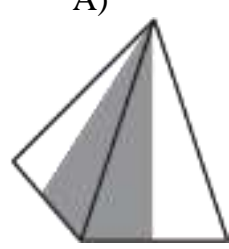

C)

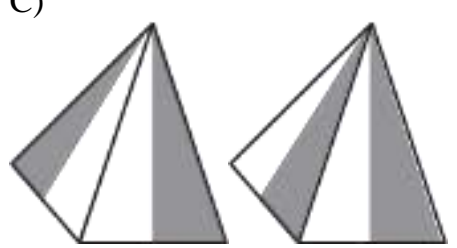

B)

D)

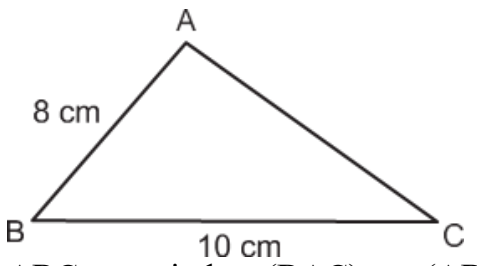

$A B C$ üçgeninde $\mathrm{m}(\mathrm{BAC})>\mathrm{m}(\mathrm{ABC}),|\mathrm{AB}|=8 \mathrm{~cm}$ ve $|\mathrm{BC}|=10 \mathrm{~cm}$ 'dir.

Buna göre $|\mathrm{AC}|$ 'nun santimetre cinsinden alabileceği kaç farklı tam sayı değeri vardır?
A) 5
B) 6
C) 7
D) 8

19. Bir kargo şirketi gönderilen kargonun kilogram cinsinden kütlesi ile desimetreküp cinsinden hacmini hesapliyor ve hangisine göre kargo ücreti fazla ise o ücreti alıyor. Bu kargo şirketine ait ücret tarifesi Tablo 1 ve Tablo 2'de verilmiştir.

Tablo 1: Kütlelerine Göre Kargo Ücreti

\begin{tabular}{|l|l|}
\hline Kütle (x kg) & Ücret (TL) \\
\hline $0<\mathrm{x} \leq 3$ & 5 \\
\hline $3<\mathrm{x} \leq 6$ & 6,50 \\
\hline $6<\mathrm{x} \leq 10$ & 8 \\
\hline
\end{tabular}

Tablo 2: Hacimlerine Göre Kargo Ücreti

\begin{tabular}{|l|l|}
\hline Hacim $\left(\mathbf{y ~ d m}^{3}\right)$ & Ücret $\mathbf{T L})$ \\
\hline $0<\mathrm{y} \leq 9$ & 5,50 \\
\hline $9<\mathrm{y} \leq 18$ & 7 \\
\hline $18<\mathrm{y} \leq 30$ & 9 \\
\hline
\end{tabular}

Buse bu kargo şirketi ile Tablo 3'te yarıçaplarının uzunlukları, yükseklikleri ve kütleleri verilen dik dairesel silindir şeklindeki kargoları yollamıştır.

Tablo 3: Kargolara Ait Bilgiler

\begin{tabular}{|l|l|l|l|}
\hline Kargo & $\begin{array}{l}\text { Yarıçapının } \\
\text { Uzunluğu } \\
(\mathbf{c m})\end{array}$ & $\begin{array}{l}\text { Yüksekliği } \\
(\mathbf{c m})\end{array}$ & $\begin{array}{l}\text { Kütlesi } \\
(\mathbf{k g})\end{array}$ \\
\hline 1. kargo & 12 & 20 & 4 \\
\hline 2. kargo & 15 & 18 & 6 \\
\hline
\end{tabular}

Buna göre Buse bu kargolar için kaç lira ödeme yapmıştır? (r yerine 3 alınız.)
A) 12
B) 12,50
C) 13
D) 13,50

Buna göre bu müşterinin fatura tutarı kaç liradır?
A) 10
B) 30
C) 50
D) 70

17. Alanı $118 \mathrm{~m} 2$ olan bir evin dikdörtgen biçimindeki odaları ve salonu dışındaki bölümlerinin toplam alanı 34 m2dir. Salonun alan1, metrekare cinsinden bir tamkare sayıdır ve odaların alanları toplamından küçüktür.

$\mathrm{Bu}$ salonun kısa kenarının uzunluğu $18 \mathrm{~m}$ olduğuna göre uzun kenarının uzunluğu en fazla kaç metredir?
A) $7 \sqrt{ } 2$
B) $6 \sqrt{ } 2$
C) $4 \sqrt{ } 2$
D) $3 \sqrt{ } 2$
18.

20. 400 metrelik düz bir yarış pistine başlangıç noktasına uzaklıkları metre cinsinden 2'nin pozitif tam say1 kuvvetleri olacak şekilde yerleştirilebilecek en fazla sayıda engel yerleştiriliyor. Bu pistte 8 atletin yarıştığı bir engelli koşusunda yarışmacılardan biri 20. metrede, bir diğeri 50. metrede yarışı bırakıyor.

Diğer yarışmacılar yarışı tamamladığına göre yarış bittiğinde atletlerin her birinin üzerinden atladığı engel sayılarının toplamı kaçtır?
A) 57
B) 63
C) 64
D)72 
